p-ISSN: 2597-4971, e-ISSN: 2685-0079

EFEKTIVITAS PROGRAM PEMBERANTASAN ILLEGAL, UNREPORTED, UNREGULATED FISHING (IUUF) MENUJU LEGAL, REPORTED, REGULATED FISHING (LRRF)

\title{
EFFECTIVITY OF ILLEGAL, UNREPORTED, UNREGULATED FISHING (IUUF) ERADICATION PROGRAM TOWARD LEGAL, REPORTED, REGULATED FISHING (LRRF)
}

(disubmit 28 Oktober 2021, direvisi 12 November 2021, diterima 23 November 2021)

\author{
Dida Daniarsyah ${ }^{1}$ Lucky Rizky Rachmadi $^{2}$ Ipah Ema Jumiati $^{3}$ \\ ${ }^{1}$ Sekretariat Jenderal, Kementerian Kelautan dan Perikanan, Jl. Medan Merdeka Timur \\ No. 16 Jakarta \\ ${ }^{2}$ Direktorat Jenderal Pengawasan Sumber Daya Kelautan dan Perikanan, Kementerian \\ Kelautan dan Perikanan, J1. Medan Merdeka Timur No. 16 Jakarta \\ ${ }^{3}$ Program Studi Magister Administrasi Publik, Gedung C Pascasarjana Universitas Sultan \\ Ageng Tirtayasa, Jl. Raya Jakarta Km.4 Pakupatan Serang \\ Corresponding Author : dida.daniarsyah@kkp.go.id, lucky.rizki.rachmadi@gmail.com, \\ ipah.ema@untirta.ac.id
}

\begin{abstract}
ABSTRAK
Indonesia merupakan negara kepulauan yang memiliki Potensi sumber daya ikan sebesar 1.772 triliun rupiah. potensi tersebut terancam musnah dengan masifnya IUUF. Pemberantasan IUUF telah dilaksanakan secara intensif mulai dari tahun 2015. Akan tetapi, permasalahannya adalah IUUF masih masif di wilayah pengelolaan perikanan Negara Republik Indonesia. Metode penelitian dilakukan dengan studi literatur, temuan data-data sekunder, wawancara dilakukan dengan snowball kepada narasumber dan informan pemilik otoritas dan praktisi yang terkait dengan praktek pemberantasan IUUF. Hasil penelitian pemberantasan IUUF melalui pemberian sanksi penenggelaman efektif membuat terapi kejut tapi tidak menimbulkan efek jera, internalisasi penyadartahuan kepada nelayan dan pelaku usaha, penguatan sarana dan prasarana pengawasan, dan penguatan peran Indonesia di Kawasan ASEAN diprediksi efektif dalam mengatasi IUUF menjadi LRRF.
\end{abstract}

Kata kunci: Efektivitas, IUUF, LRRF, penagkapan ikan

\section{ABSTRACT}

Indonesia is an archipelagic country that has potential fish resources of 1.772 trillion rupiahs. this potential is threatened with extinction by the massive IUUF. IUUF eradication has been carried out intensively starting from 2015. However, the problem is that IUUF is still massive in the fisheries management area of the Republic of Indonesia. The research method was carried out by studying literature, finding secondary data, interviews conducted by snowball to resource persons and informants who have authorities and practitioners related to the practice of eradicating IUUF. The results of research on eradicating IUUF through imposing drowning sanctions are effective in making shock therapy but not causing a deterrent effect, internalizing awareness to fishermen and business actors, strengthening monitoring facilities and infrastructure, and strengthening Indonesia's role in the ASEAN Region.

Keywords : Effectivity, IUUF, LRRF, fishing 
Jurnal Kebijakan Pembangunan Daerah, Vol.5, No.2, Desember 2021, Hal. 110 - 122

p-ISSN: 2597-4971, e-ISSN: 2685-0079

\section{PENDAHULUAN}

Indonesia merupakan negara kepulauan terbesar di dunia, hal ini ditunjukkan dengan data luas wilayah kepulauan Republik Indonesia berdasarkan kajian BIG (Badan Informasi Spesial) dan Pushidros (Pusat Hidrologi dan Oseanograpi) tahun 2015 (Biro Komunikasi Kemenkomar, 2018) yaitu:

1. Luas perairan pedalaman dan perairan kepulauan Indonesia adalah $3.110 .000 \mathrm{~km} 2$;

2. Luas laut teritorial Indonesia adalah $290.000 \mathrm{~km} 2$;

3. Luas zona tambahan Indonesia adalah 270.000 km2;

4. Luas zona ekonomi eksklusif Indonesia adalah $3.000 .000 \mathrm{~km} 2$;

5. Luas landas kontinen Indonesia adalah 2.800.000 km2;
6. Luas total perairan Indonesia adalah $6.400 .000 \mathrm{~km} 2$;

7. Luas NKRI (darat + perairan) adalah 8.300.000 km2;

8. Panjang garis pantai Indonesia adalah $108.000 \mathrm{~km}$; dan

9. Jumlah pulau di Indonesia kurang lebih 17.504, dan yang sudah dibakukan dan disubmisi ke PBB adalah sejumlah 16.056 pulau atau 81 persen dari seluruh wilayah Indonesia.

Indikasi lain terkait besarnya sumber daya sebagai negara kepulauan dapat ditunjukkan dengan hasil penelitian Komisi Nasional Pengkajian Stok Ikan (Komnasjiskan) pada tahun 2018 melaporkan bahwa stok ikan Indonesia sebanyak 12,5 juta ton. Hal ini menunjukkan bahwa terjadi tren

Ancaman Pencurian Ikan di Wilayah Perairan Indonesia

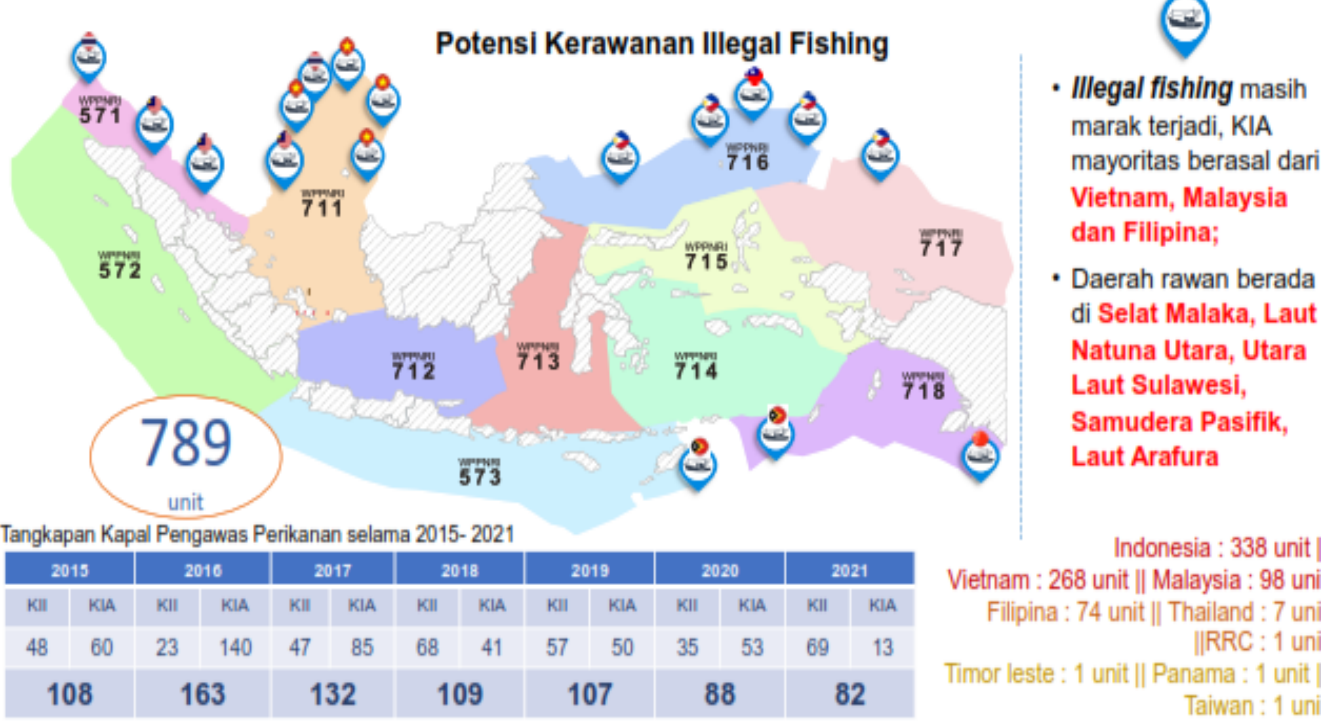

Gambar 1. Data Tangkapan Pelaku UUF (Sumber: DPSDKP-KKP, 2021) 
p-ISSN: 2597-4971, e-ISSN: 2685-0079

ketersediaan stok ikan naik yang pada tahun 2015 sekitar 9,93 juta ton. Demikian pula dengan biomassa laut Indonesia menurut Komnasjiskan naik sekitar 300 persen. Ini berarti 3 kali lebih baik daripada lautan-lautan di belahan dunia lainnya.

Dengan modal kekayaan laut Indonesia di atas, sangat wajar kalau seharusnya bangsa Indonesia sejahtera apabila mampu mengelola dan memanfaatkan kekayaan laut tersebut. Namun demikian, sampai saat ini (2021) masih terdapat nelayan berada pada taraf hidup miskin, kontribusi produksi perikanan rata-rata hanya 3,2 persen terhadap produk domestik bruto (PDB) Indonesia, angka yang sangat tidak wajar untuk sebuah negeri bahari (KKP, 2020).

Di sisi lain, besarnya potensi sumber daya ikan di Wilayah Pengelolaan Perikanan Negara Republik Indonesia (WPPNRI) menjadi magnet bagi Kapal Ikan Asing (KIA) untuk menangkap ikan di perairan Indonesia. Namun, KIA tersebut menangkap ikan dengan cara IUUF (Irregular Unreported, Unregulated, Fishing), sehingga Indonesia sejak tahun 2015 membuat kebijakan untuk memerangi atau memberantas IUUF melalui kebijakan pemberantasan IUUF dengan penenggelaman kapal sebagai vonis terhadap pelaku.

Kondisi IUUF sampai pada tahun 2021 masih marak atau masif terjadi di WPPNRI. Terdapat data yang dapat menunjukkan masih maraknya IUFF di WPPNRI oleh KIA dan Kapal Ikan Indonesia (KII).

Kurun waktu tahun 2020-2021 terdapat 170 unit kapal pelaku IUUF. Pelaku IUUF mayoritas berasal dari negara Vietnam, Malaysia dan Filipina. Daerah rawan berada pada Selat Malaka, Laut Natuna Utara, Laut Sulawesi, Samudera Pasifik, Laut Arafura. Hal ini juga menunjukkan masih marak terjadi IUUF, yang seharusnya dalam kurun waktu 5 (lima) tahun tersebut kebijakan penenggelaman kapal efektif menghilangkan IUUF pada WPPNRI menuju LRRF.

Beberapa penelitian terdahulu tentang IUUF telah banyak dilakukan. Akan tetapi, dominan fokus penelitian pada kebijakan sanksi penenggelaman terhadap pelaku IUUF. Penelitian tersebut antara lain, Tinjauan Yuridis Illegal Fishing di Indonesia berdasarkan UndangUndang Perikanan. Simpulannya adalah dalam undang-undang Perikanan Nomor 45 Tahun 2009 sanksi terhadap pelaku IUUF lebih berat. Akan tetapi tidak serta merta membuat efek jera (Inggrit, 2017). 
p-ISSN: 2597-4971, e-ISSN: 2685-0079

Penegakan hukum IUUF yang dapat dilakukan Pemerintah Indonesia adalah hukuman pidana penjara, pembakaran/ penenggelaman kapal, denda setelah mengalami proses hukum di pengadilan perikanan (Harliza \& Michael, 2020). Aprizal dan Muslimah (2019) meneliti tentang Penegakkan hukum IUUF terhadap kapal KM BD 95599 hasil penelitiannya adalah proses penegakan terhadap Kapal KM BD 95599 TS beserta nahkoda dan awak kapal KM BD 95599 TS sudah sesuai dengan ketentuan yang ada dalam hukum internasional dan hukum nasional, penegakan hukum hanya terbatas pada pemberian sanksi pidana denda tanpa adanya pidana penjara. Maryani dan Nasution (2019) menyimpulkan hasil penelitian pada rekonsepsi model yang digunakan dalam pencegahan maupun pemberantasan IUUF, yaitu membentuk sistem pemantauan terhadap kapal perikanan Sistem Pemantau Kapal Perikanan (SPKP), pembuatan peraturan yang berkaitan dengan kelautan dan kegiatan IUUF, penegakan hukum terhadap pelaku kegiatan IUUF, kerja sama internasional. Kusumawardhani (2020) menyimpulkan hasil penelitiannya bahwa berdasarkan pada fakta hukum yang terjadi, peraturan perundang - undangan nasional dan hukum internasional publik mengenai perikanan tangkap, kelautan, ZEE, serta penanganan IUUF, dan mendasarkan pada teori legal positivism, maka kesimpulan yang dihasilkan mengenai legalitas kebijakan dan tindakan penenggelaman kapal - kapal asing pelaku IUUF di ZEE Indonesia adalah sebagai sesuai dengan terori legal positivism.

Selanjutnya, penenggelaman kapal asing pelaku IUUF tersebut menjadi langkah konkrit komitmen Pemerintah Indonesia yang telah menyatakan diri untuk terikat dalam berbagai instrumen hukum internasional terkait dalam menghadapi permasalahan IUUF dan konsevasi sumber daya kelautan.

Penelitian ini terdapat perbedaan dengan penelitian terdahulua. Kebaruan penelitian ini adalah bagaimana implementasi pemberantasan IUUF dilaksanakan dan menyajikan fakta dan data terkait pelaksanaan atau implementasi kebijakan dalam memberantas IUUF menuju LRRF. Sehingga dapat mengukur efektivitas kebijakan yang dinilai telah efektif dengan beberapa rekomendasi yang akan memberikan strategi tambahan kelanjutan pemberantasan IUUF menuju LRRF.

Menurut penulis, bahwa kebijakan pemberantasan IUFF merupakan kebijakan yang bersifat top down. Pendekatan top down bersifat aktor yang 
Jurnal Kebijakan Pembangunan Daerah, Vol.5, No.2, Desember 2021, Hal. 110 - 122

p-ISSN: 2597-4971, e-ISSN: 2685-0079

menjadi pelaksana dalam kebijakan sangat

mengembangkan konsep dan dominan (Purwanto \& Sulistyastuti, 2012) atau dapat disepadankan dengan pendekatan commond center (Deleon dan Deleon, 2002). Namun dalam penelitian ini akan difokuskan pada kinerja implementasi kebijakan IUUF menuju LRRF. Pendekatan teoritis yang dijadikan kerangka dalam berpikir menggunakan kerangka logis pengukuran kinerja Implementasi yang dijelaskan oleh Cole dan Parston (2006).

Penelitian ini bertujuan untuk mengukur efektivitas kinerja kebijakan pemberantasan IUUF menuju LRRF di Indonesia dari tahun 2015 sampai dengan tahun 2020.

\section{METODE}

Peneliti menggunakan penelitian bersifat deskriptif melalui pendekatan kualitatif, analisis melalui studi litratur dan dokumentasi, baik dari buku buku kepustakaan, media baik cetak maupun elektronik. Pengumpulan data dilakukan dengan wawancara secara snowball kepada narasumber, informan, responden, stakeholder yang terkait dengan masalah penelitian. Singarimbun dan Effendi (2009) menyatakan pendapatnya bahwa penelitian deskriptif dimaksud untuk mengukur dengan cermat terhadap fenomena sosial tertentu, di mana peneliti

\section{IUUF dalam Persfektif Kebijakan Internasional}

Ditinjau dari konteks kejahatannya, IUUF dapat dikatakan sebagai bagian dari transnational organized crime (Bondaroff, et al., 2015), hal ini dikarenakan dalam kebanyakan kasus yang terjadi memiliki beberapa ciri yang serupa. Pertama, adanya kolaborasi lebih dari dua orang yang terlibat. Operasi penangkapan ikan bukan upaya tunggal, operasi ini melibatkan nelayan itu sendiri, pemilik kapal, penyandang dana, dan pihak lainnya berkolaborasi dalam pembiayaan dan melaksanakan operasi penangkapan ikan, serta dalam penjualan akhir dari ikan tersebut. Kedua, IUUF beroperasi dalam level internasional. Penangkapan ikan secara ilegal dapat terjadi di perairan satu negara, lintas batas atau di laut lepas. Ikan yang ditangkap secara ilegal diangkut dan dijual di berbagai negara. Ketiga, pelaku kejahatan tersebut umumnya menggunakan berbagai strategi pencucian keuangan untuk 
p-ISSN: 2597-4971, e-ISSN: 2685-0079

menyembunyikan keuntungan dan hasil dari tangkapan ilegal mereka. Tentunya ada banyak tahapan dalam rantai pasokan industri perikanan dimana keuntungan dari penangkapan ikan secara ilegal dikelola sedemikian rupa sehingga tampak menjadi keuntungan yang legal dan sah, proses tersebut dikenal sebagai pencucian uang. Dana gelap tersebut dapat diinvestasikan dalam infrastruktur (peralatan baru, pabrik, pengelahan ikan, kapal) atau dalam kepentingan operasional (penangkapan, memproses, dan transportasi).

Pandangan IUUF menurut sumber FAO dan RFMO menyatakan bahwa International Plan of Action (IPOA) 2001, implementasi Code of Conduct for Responsible Fisheries (CCRF) memberikan pengertian Illegal Fishing dijelaskan sebagai berikut:

1) Kegiatan penangkapan ikan yang dilakukan oleh suatu negara tertentu atau kapal asing di perairan yang bukan merupakan yurisdiksinya tanpa izin dari negara yang memiliki yurisdiksi atau kegiatan penangkapan ikan tersebut bertentangan dengan hukum dan peraturan negara itu.

2) Kegiatan penangkapan ikan yang dilakukan oleh kapal perikanan berbendera salah satu negara yang tergabung sebagai anggota organisasi pengelolaan perikanan regional, Regional Fisheries Management Organization (RFMO) tetapi pengoperasian kapal-kapalnya bertentangan dengan tindakantindakan konservasi dan pengelolaan perikanan yang telah diadopsi oleh RFMO. Negara RFMO wajib mengikuti aturan yang ditetapkan itu atau aturan lain yang berkaitan dengan Hukum Internasional.

3) Kegiatan perikanan yang bertentangan dengan hukum nasional atau kewajiban
IUU FISHING DIMULAI DARI HULU SAMPAI DENGAN HILIR

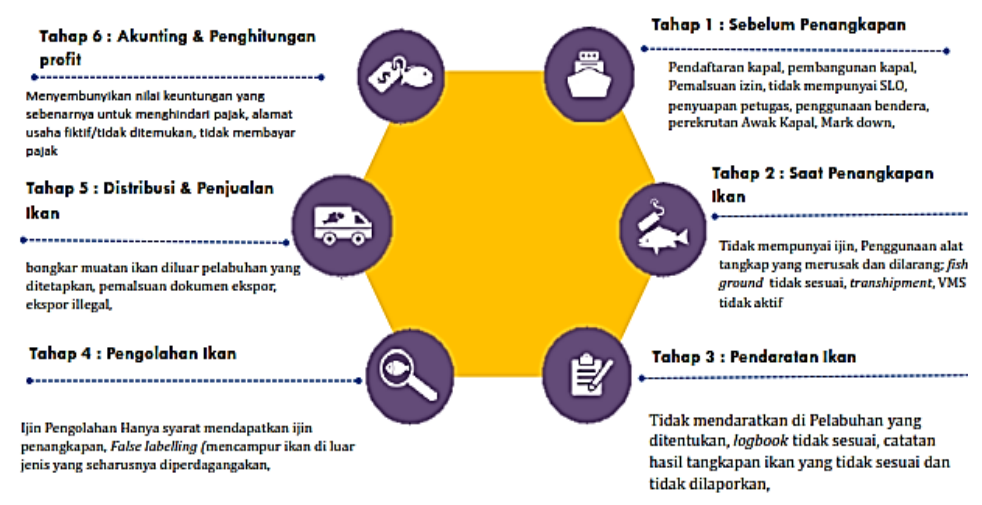

Gambar 2. Fakta tahap IUUF Sumber: DJPSDKP-KKP, 2021 internasional, termasuk juga kewajiban negaranegara anggota organisasi pengelolaan perikanan regional terhadap organisasi tersebut; dan

4) Kegiatan penangkapan ikan yang melanggar hukum yang paling umum terjadi di Wilayah Penangkapan Perikanan Negara Republik 
Jurnal Kebijakan Pembangunan Daerah, Vol.5, No.2, Desember 2021, Hal. 110 - 122

p-ISSN: 2597-4971, e-ISSN: 2685-0079

Indonesia adalah pencurian ikan oleh kapal penangkap ikan berbendera asing, khus usnya dari beberapa negara tetangga.

\section{Hasil Implementasi pemberantasan IUUF menuju LRRF di Indonesia}

Indonesia dikenal sebagai Marine Mega-Biodiversity terbesar di dunia. Hasil riset yang dilakukan oleh Puji Rahmadi, peneliti dari Pusat Penelitian Oseanografi Lembaga Ilmu Pengetahuan Indonesia (P2O LIPI, 2019), mengungkapkan bahwa nilai kekayaan laut di Indonesia ternyata mencapai Rp 1.772 triliun. Namun, potensi laut Indonesia terganggu akibat ancaman dari adanya IUUF.

Indonesia memiliki pandangan tidak hanya pada IUUF, akan tetapi penangkapan ikan yang disertai dengan tidak memenuhi peraturan dan tidak melaporkan hasil tangkapan juga merupakan kejahatan atau praktek illegal.

Sehingga kebijakan yang diputuskan
Penanggulangan Illegal, Unreported and Unregulated Fishing Tahun 2012-2016 dan Keputusan Menteri KP Nomor 39/PERMEN-KP/2019 tentang

Pelaksanaan Ketentuan Negara Pelabuhan untuk mencegah, menghalangi, dan memberantas Penagkapan Ikan Secara Ilegal, Tidak dilaporkan dan Tidak diatur.

Dalam regulasi tersebut kebijakan yang dituangkan terkait IUUF di Indonesia adalah kegiatan Illegal Fishing di perairan Indonesia dalam bentuk: 1) penangkapan ikan tanpa izin; 2) penangkapan ikan dengan menggunakan izin palsu; 3) Penangkapan ikan menggunakan alat tangkap yang dilarang; dan 4) Penangkapan jenis (spesies) ikan yang dilarang, atau tidak sesuai dengan izin.

Sedangkan Kegiatan Unreported Fishing di Indonesia antara lain: emalsuan data tangkapan, atau tidak melaporkan hasil tangkapan yang dengan sesungguhnya dan membawa hasil adalah memberantas IUUF dengan menerbitkan regulasi Keputusan Menteri Kelautan dan Perikanan Nomor

KEP.50/MEN/2012

tentang Rencana Aksi Nasional Pencegahan dan

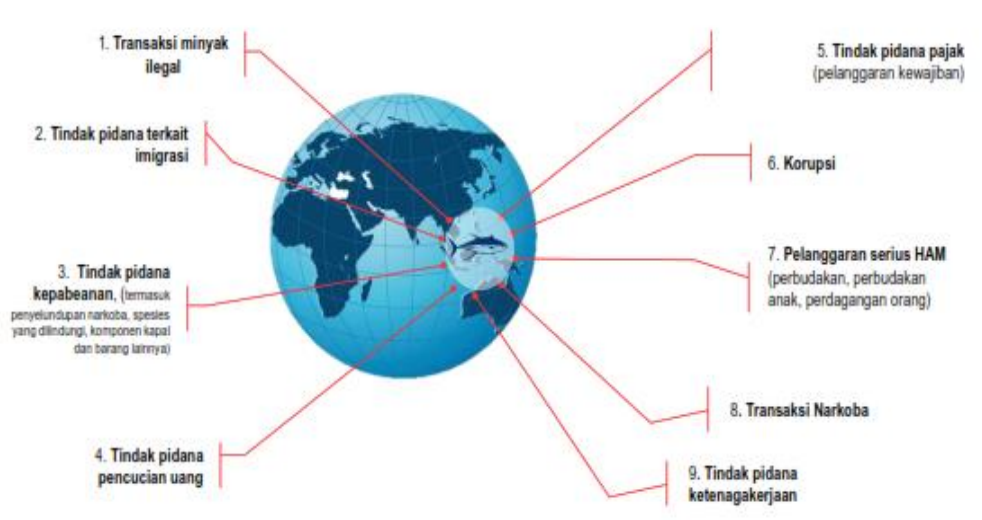

Gambar 4. Fakta Keterkaitan IUUF dengan Kejahatan lainnya Sumber: DJPSDKP-KKP, 2021 
Jurnal Kebijakan Pembangunan Daerah, Vol.5, No.2, Desember 2021, Hal. 110 - 122

p-ISSN: 2597-4971, e-ISSN: 2685-0079

tangkapan langsung

ke negara lain

(transhipment di laut).

Kegiatan

\section{Unregulated Fishing}

di perairan Indonesia, antara lain masih belum diaturnya: 1) mekanisme

pencatatan data hasil tangkapan dari

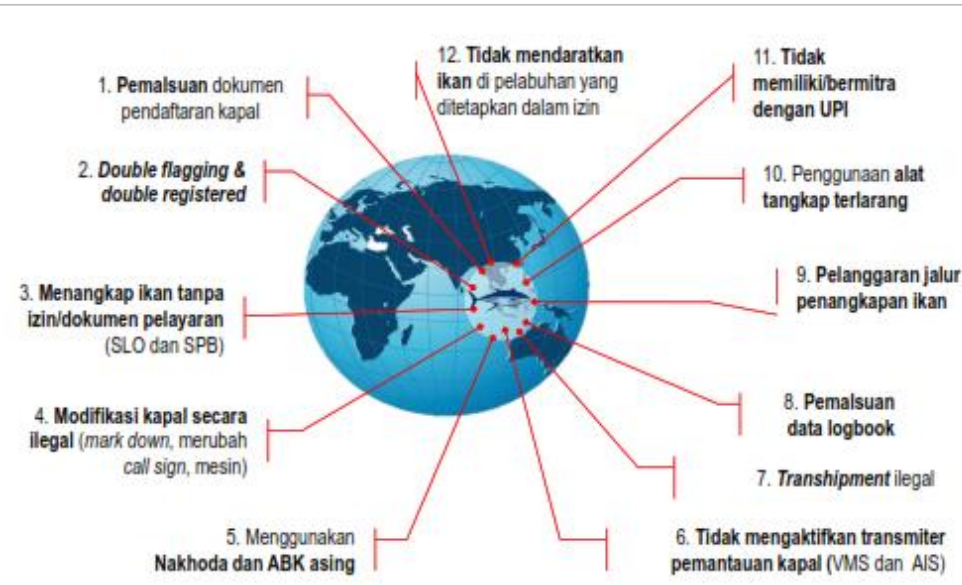

Gambar 3 menunjukkan modus operandi IUUF. Sumber: DJPSDKP-KKP, 2021 seluruh kegiatan penangkapan ikan yang ada; 2) wilayah perairan-perairan yang diperbolehkan dan dilarang; 3) pengaturan aktivitas sport fishing; dan 4) Penggunaan alat penangkap ikan yang belum diatur

Kebijakan pemberantasan IUUF telah dilaksanakan secara masif sejak tahun 2015. Dari penelusuran praktek IUUF dilapangan bahwa IUUF dapat terjadi dari hulu sampai hilir. Gambar 2 menunjukkan fakta terungkap terdapat 6 tahap IUUF.

Fakta lain terungkap bahwa terdapat modus operandi dalam IUUF. Gambar 3 menunjukkan modus operandi IUUF.

Praktek IUUF ternyata berimplikasi dengan keterkaitan kejahatan lainnya. Gambar 4 menujukkan keterkaitan kejahatan IUUF dengan kejahatan lainnya.

Pemberantasan IUUF telah menyasar kepada awak kapal dan nelayan.
Tabel 1 dan Tabel 2 Menunjukkan data awak kapal dan nelayan yang ditangani.

Tabel 1. Penanganan terhadap Awak Kapal Ilegal ditangkap di Indonesia dari tahun 2015 sampai tahun 2020

\begin{tabular}{|c|c|c|}
\hline $\begin{array}{c}\text { Jumlah } \\
\text { AK }\end{array}$ & $\begin{array}{c}\text { Sudah } \\
\text { dipulang } \\
\text { kan }\end{array}$ & Masih di Indonesia \\
\hline $\begin{array}{l}1283 \\
\text { orang }\end{array}$ & $\begin{array}{l}705 \\
\text { orang }\end{array}$ & $\begin{array}{l}\text { - } 47 \text { orang menunggu } \\
\text { pemulangan } \\
\text { - } 152 \text { orang proses } \\
\text { hokum } \\
\text { - } 379 \text { orang } \\
\text { saksi/bukan tersangka }\end{array}$ \\
\hline
\end{tabular}

Tabel 2. Penanganan terhadap Nelayan Indonesia yang Tertangkap di LN dari tahun 2015 sampai tahun 2020

\begin{tabular}{|c|c|c|}
\hline $\begin{array}{c}\text { Jumlah } \\
\text { AK }\end{array}$ & $\begin{array}{c}\text { Sudah } \\
\text { dipulangk } \\
\text { an } \\
\end{array}$ & $\begin{array}{l}\text { Menunggu proses } \\
\text { pemulangan }\end{array}$ \\
\hline $\begin{array}{l}170 \\
\text { orang }\end{array}$ & $\begin{array}{l}122 \\
\text { orang }\end{array}$ & $\begin{array}{l}\text { - } 10 \text { orang (Malaysia) } \\
\text { - } 3 \text { orang (India) } \\
\text { - } 28 \text { orang (Thailand) } \\
\text { - } 7 \text { orang (Papua } \\
\text { Nugini) }\end{array}$ \\
\hline
\end{tabular}

Sumber: DJPSDKP-KKP, per 29 Oktober 2021 
Jurnal Kebijakan Pembangunan Daerah, Vol.5, No.2, Desember 2021, Hal. 110 - 122

p-ISSN: 2597-4971, e-ISSN: 2685-0079

Tabel 3. Grand Design Kebutuhan Kapal Pengawas

\begin{tabular}{|l|c|c|c|c|}
\hline $\begin{array}{l}\text { Kelas } \\
\text { Kapal }\end{array}$ & $\begin{array}{c}\text { Panjang } \\
\text { LOA } \\
(\text { meter) }\end{array}$ & Existing & $\begin{array}{c}\text { Kondisi } \\
\text { Ideal }\end{array}$ & Kebutuhan \\
\hline A & $>50$ & 4 & 14 & 10 \\
\hline B & $40-50$ & 2 & 20 & 18 \\
\hline C & $30-40$ & 13 & 21 & 8 \\
\hline D & $20-30$ & 10 & 15 & 5 \\
\hline E & $15-20$ & 1 & - & - \\
\hline \multicolumn{2}{|c|}{ TOTAL } & $\mathbf{3 0}$ & $\mathbf{7 0}$ & $\mathbf{4 1}$ \\
\hline
\end{tabular}

Sumber : DJPSDKP-KKP, 2021

Strategi pemberantasan IUUF lainnya yang telah dilakukan Indonesia adalah pengawasan pemanfaatan sumber daya kelautan dan perikanan dengan system pengawasan terpadu berbasis Internet of Things (IoT), Penguatan armada pengawasan dan peningkatan operasi pengawasan, dan Penguatan peran Indonesia di Kawasan ASEAN

Rencana penguatan armada pengawasan dan peningkatan operasi pengawasan seperti ditunjukan pada Tabel 3.

Model pengawasan berbasisi IoT telah dilaksanakan (Talita dkk, 2016). Hal ini dapat ditunjukkan pada Gambar 5.

Penguatan armada menjadi

kebijakan pilihan pemberantasan dalam karena saat
IUUF ini ketersediaan armada pengawasan sejumlah 30 unit belum maksimal menjangkau titik pengawasan WPPNRI.

Selanjutnya, implementasi pemberantasan IUUF dilaksanakan dengan memainkan peran diplomasi Indonesia di kawasan Internasional dan ASEAN. Melalui penulusuran data sekunder maka didapatkan peran Indonesia dalam memanfaatkan forumforum meeting sebagai upaya diplomasi mempropagandakan pemberantasan IUUF.

Pada tahun 2015, Indonesia juga telah memprakarsai disepakatinya EAS Statement on Enhancing Regional Maritime Cooperation yang mencakup 5 pilar kerja sama maritim di Kawasan. Dalam kerja sama tersebut, pemberantasan dan pencegahan IUUF menjadi bagian penting yang berhasil disepakati.

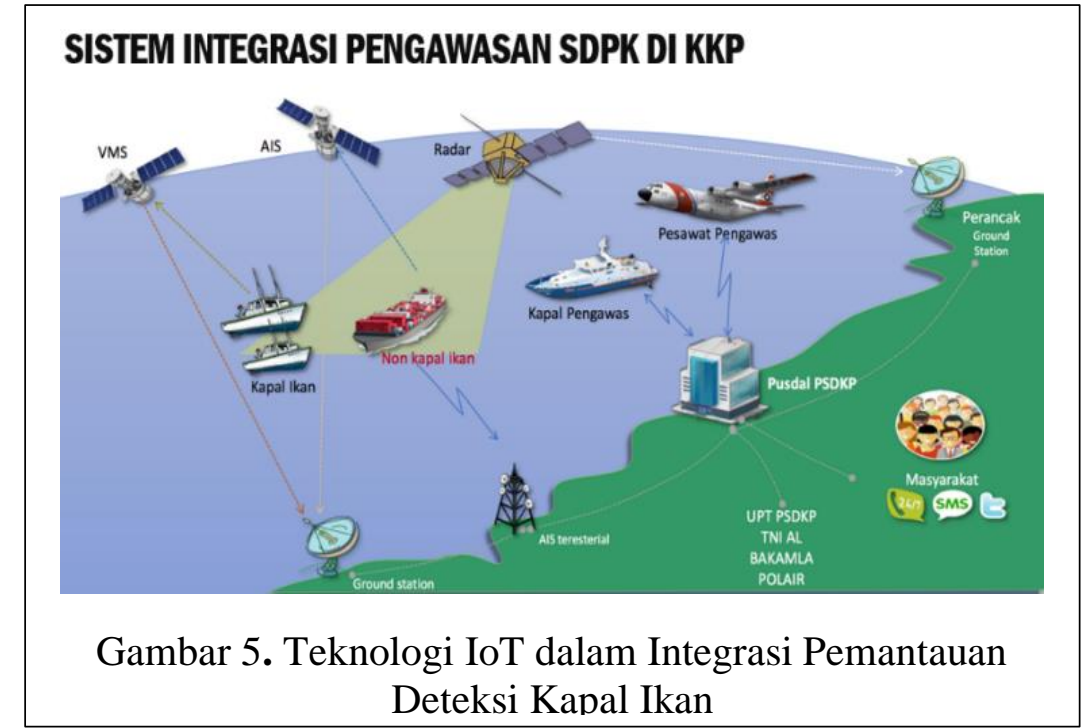


p-ISSN: 2597-4971, e-ISSN: 2685-0079

Kerja sama terkait IUUF dibahas dalam konteks penanganan isu-isu lintas batas (transboundary challenges), lingkungan laut (marine environment), serta kerja sama pencegahan produksi hasil-hasil perikanan jika dihasilkan dari aktifitas IUUF.

Pada saat menjadi tuan rumah Pertemuan ASEAN Maritime Forum ke-6 dan Expanded ASEAN Maritime Forum (EAMF) ke-4 di Manado, September 2015, Indonesia secara khusus mengangkat pentingnya penanggulangan isu IUUF.

Pada pertemuan ini, Indonesia kembali mengusulkan dibentuknya pengaturan regional penanggulangan IUUF dan mengajak negara-negara di Kawasan untuk mendukung inisiatif ini.

Dalam mekanisme ASEAN Regional Forum (ARF), Indonesia telah berhasil memasukkan kerja sama penanganan IUUF dalam dokumen kerja ARF di bidang keamanan maritim, yaitu ARF Work Plan on Maritime Security 2015-2017.

Sebagai implementasinya, Indonesia, bersama Amerika Serikat, telah menyelenggarakan 2 (dua) workshop terkait IUUF, yakni ARF Workshop on Improving Fisheries Management di Honolulu pada Maret 2016 dan ARF
Workshop on IUUF di Bali pada April 2016.

Kerja sama lain dalam bentuk Joint Statement of the ASEAN-U.S. Special Leaders' Summit: Sunnylands Declaration yang disepakati pada Februari 2016 di AS. Selain itu, isu IUUF telah masuk dalam Plan of Action (PoA), rujukan berbagai kegiatan, antara ASEAN dengan Mitra Wicaranya, seperti dalam ASEAN - US PoA, ASEAN - China PoA, ASEAN - Canada PoA, ASEAN - India PoA, ASEAN - New Zealand PoA, ASEAN - RoK PoA, ASEAN- Russia POA.

Mengukur kinerja efektivitas pemberantasan IUUF berdasarkan temuan data dan fakta di atas pada indikator tujuan kebijakan telah efektif menurunkan tingkat IUUF. Walaupun masih marak terjadi IUUF, hal tersebut lebih ditentukan oleh komitmen negara pelaku IUUF di Kawasan ASEAN dan Global yang belum maksimal dalam mendorong tingkat kepatuhan nelayan dan pelaku usaha menyadari bahaya IUUF.

Indikator output pemberantasan IUUF adalah semakin menurunya tingkat IUUF dan semakin tinggi tingkat kesepahaman dan kesadaran terhadap komitmen pemberantasan IUUF di negara mitra wicara seperti ASEAN. 
Jurnal Kebijakan Pembangunan Daerah, Vol.5, No.2, Desember 2021, Hal. 110 - 122

p-ISSN: 2597-4971, e-ISSN: 2685-0079

Tabel 4. Data Produksi dan Ekspor 2015 - 2019

\begin{tabular}{|c|c|c|c|c|c|c|}
\hline \multirow{2}{*}{ Uraian } & \multicolumn{5}{|c|}{ Nilai USD Juta } & \multirow{2}{*}{$\begin{array}{c}\text { Rata rata } \\
\text { kenaikan } \\
(\%)\end{array}$} \\
\hline & 2015 & 2016 & 2017 & 2018 & 2019 & \\
\hline $\begin{array}{l}\text { Pasar } \\
\text { Dunia }\end{array}$ & 133.894 & 141.693 & 156.022 & 163.436 & 162.749 & $5,05 \%$ \\
\hline Ekspor & 3.944 & 4.172 & 4.524 & 4.861 & 4.936 & $5,80 \%$ \\
\hline $\begin{array}{l}\text { Persentase Indonesia } \\
\text { Terhadap dunia }\end{array}$ & $2,94 \%$ & $2,94 \%$ & $2,90 \%$ & $2,97 \%$ & $3,03 \%$ & $0,76 \%$ \\
\hline
\end{tabular}

Sumber: BPS (2020) dan UN Comtrade Database (2020)

Indikator outcome dengan melimpahnya stok ikan di WPPNRI berdampak terhadap tingkat tangkapan atau produksi ikan bagi nelayan bahkan ekspor akan meningkat, sehingga tingkat kesejahteraan masyarakat meningkat.

Peningkatan ini dapat ditunjukkan dengan data tahun 2019 nilai pasar produk perikanan dunia USD 162,7 miliar, ekspor Indonesia USD 4,9 miliar (3,03\%), secara detail dapat dibaca dalam Tabel 4.

Gambar 6 Menunjukkan data produksi perikanan (juta ton) s.d tahun 2020

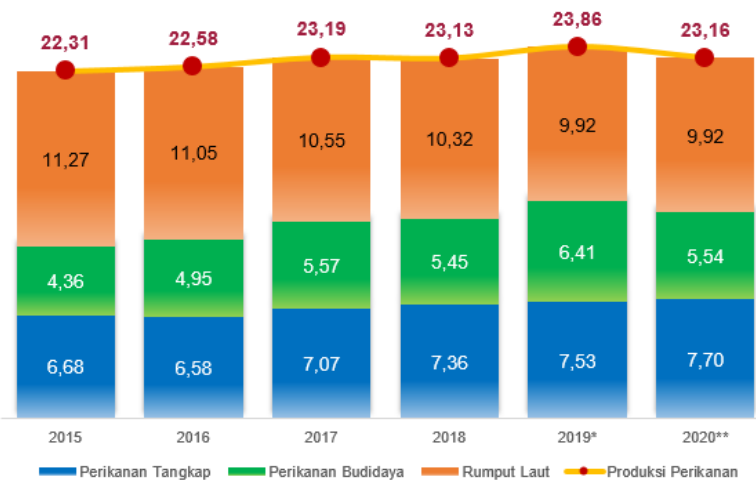

Gambar 6. Produksi Perikanan (juta ton)

$2015-2020$

Sumber: 2015-2016 DJPT dan DJPB, 2017-2020

Aplikasi Satu Data KKP

*) angka sementara

**) angka sangat sementara
Sedangkan Gambar 7 menunjukan data nilai produksi perikanan ( $\mathrm{Rp}$ triliun) tahun 2015 s.d 2020.

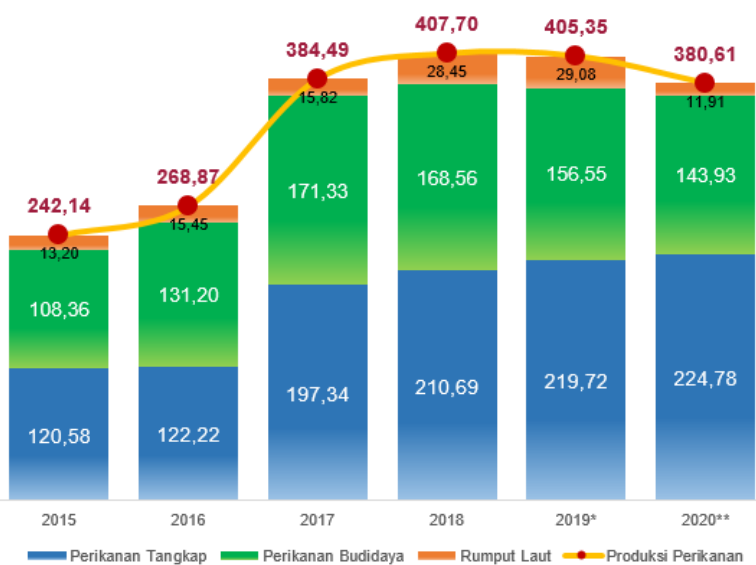

Tabel 7. Nilai Produksi Perikanan ( $\mathrm{Rp}$ triliun) 2015 - 2020

Sumber: 2015-2016 DJPT dan DJPB, 2017-2020

Aplikasi Satu Data KKP

*) angka sementara

**) angka sangat sementara

Strategi IUUF dengan menguatkan armada dan operasinya, penyadartahuan nelayan dan pelaku usaha dengan proses internalisasi maka IUUF akan menjadi LRRF. 
p-ISSN: 2597-4971, e-ISSN: 2685-0079

\section{KESIMPULAN DAN REKOMENDASI}

\section{Kesimpulan}

Pemberantasan IUUF bukanlah isu baru. Isu ini telah diatur dalam berbagai instrumen internasional seperti dalam UNCLOS, FAO, dan RFMO.

Indonesia semakin gencar mengupayakan penguatan kerja sama pemberantasan IUUF dengan negaranegara Mitra Wicara ASEAN. Berbagai statement dan dokumen kerja sama dengan negara Mitra, telah diupayakan mengakui isu IUUF menjadi bagian penting dan termasuk di dalamnya. Masih maraknya IUUF lebih ditentukan oleh aspek eksternal di kawasan ASEAN.

Vonis penenggelaman kapal tidak membuat efek jera, tetapi telah memberikan efek kejut terhadap pelaku IUUF.

\section{Upaya-upaya yang dilakukan} Indonesia dalam memajukan kerja sama dan pembahasan isu IUUF di ASEAN utamanya dilakukan melalui dua pilar, yakni pilar Politik dan Keamanan ASEAN dan pilar Ekonomi ASEAN.

Berbagai kebijakan serta upaya peningkatan pemberantasan IUUF terus dilakukan oleh Pemerintah Indonesia melalui KKP:

1. Perbaikan dan penerbitan sejumlah peraturan baru,
2. Penguatan armada pengawasan dan publikasi data kapal pencuri ikan,

3. Pengetatan pemantauan kapal penangkap ikan dengan IoT,

4. Internalisasi penyadartahuan nelayan dan pelaku usaha terhadap dampak IUUF,

5. Penguatan peran Indonesia di Kawasan ASEAN dan global,

6. Peningkatan penegakan hukum, termasuk penenggelaman kapal-kapal asing yang tertangkap tangan dan terbukti melakukan kegiatan IUUF di perairan Indonesia yang banyak mendapat sorotan dari masyarakat nasional dan internasional.

\section{Rekomendasi}

Regulasi yang sudah tidak sesuai dengan kebutuhan dan tuntutan publik sudah waktunya dilakukan revisi.

Penambahan prosentase anggaran pengadaan aramada pengawasan, updating teknologi pengawasan, pengingkatan kompetensi sumber daya manusia pengawasan, frekuensi penyedartahuan bahaya IUUF secara terpadu antar kementerian dan lembaga yang terkait. 
p-ISSN: 2597-4971, e-ISSN: 2685-0079

\section{REFERENSI}

Aprizal, F. \& Muslimah, S., (2019). Penegakan Hukum Terhadap Kasus Illegal, Unreported, Dan Unregulated Fishing yang Dilakukan Terhadap Kapal KM BD 95599 TS di Laut Natuna Sesuai Dengan Hukum Internasional. Belli Ac Pacis, 5(2).

Biro Komunikasi Kemenkomar, (2018). Menko Maritim Luncurkan Data Rujukan Wilayah Kelautan Indonesia. https://maritim.go.id/ menko-maritim-luncurkan-datarujukan-wilayah-kelautan-indonesia/ [Diakses pada 13 Oktober 2021].

Bondaroff, T. N. P., van der Werf, W. \& Reitano, T., (2015). The Illegal Fishing and Organized Crime Nexus: Illegal Fishing as Transnational Organized Crime. Geneva: The Global Initiative Against Transnational Organized Crime dan The Black Fish.

BPS. (2020). Ekspor Indonesia, diolah Ditjen PDS - KKP (480 kode HS 8 digit).

Cole, M. \& Parston, G., (2006). Unlocking Public Value. New Jersey: John Wiley \& Sons, Inc.

Deleon, L. \& Deleon, P., (2002). The Democratic Ethos and Public Management. Administration \& Society, 34(2), pp. 229-250.

Harliza, E. R. \& Michael, T., (2020). Penegakan Hukum Illegal Fishing. Mimbar Keadilan, 13(1).
Inggrit, F., (2017). Tinjauan Yuridis Illegal Fishing di Indonesia Berdasarkan Undang-Undang Perikanan. Republika, Volume 17, pp. 189-209.

Kusumawardhani, I., (2020) Kebijakan Penenggelaman Kapal Ikan Asing sebagai Komitmen Pemerintah dalam Pemberantasan IUU Fishing. Opinio Juris, Volume 26, pp. 23-56.

Maryani, H. \& Nasution, A., (2019) Rekonsepsi Model Pemberantasan Illegal Fishing di Perairan Indonesia (Analisis Perspektif Hukum Internasional). Legislasi Indonesia, 16(3).

UN Comtrade Database. (2021). ITC calculations based on UN Comtrade and ITC statistics. https://comtrade.un.org/data

Purwanto, E. A. \& Sulistyastuti, D. R., (2012). Implementasi Kebijakan Publik: Konsep dan Aplikasinya di Indonesia. 1 ed. Yogyakarta: PT Gavamedia.

Singarimbun, M. \& Effendi, S., (2009). Metode Penelitian Survai. Jakarta: LP3ES.

Talita, A., Isnanto, R., \& Kurniawan K.T. (2016). Pembuatan Aplikasi Pengembangan Sistem Pengawasan Kepatuhan Berbasis Web Pada Perusahaan Kontraktor Pertambangan, Fakultas Teknik Universitas Diponegoro, Jurnal Teknologi dan Sistem Komputer, 4(01). 